\title{
Relationship between well-being, quality of life and hope in family caregivers of schizophrenic people
}

\author{
Relação entre bem-estar, qualidade de vida e esperança em cuidadores familiares de pessoas esquizofrênicas \\ Relación entre bienestar, calidad de vida y esperanza en cuidadores familiares de personas esquizofrénicas
}

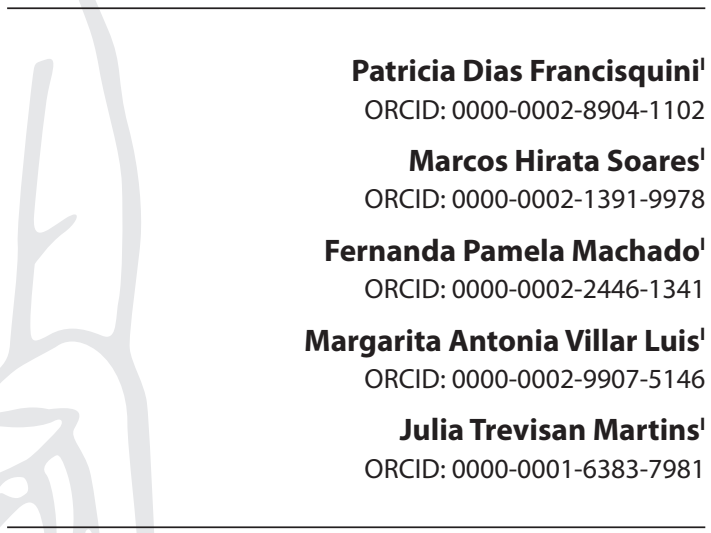

'Universidade Estadual de Londrina. Londrina, Paraná, Brazil.

How to cite this article:

Francisquini PF, Soares MH, Machado FP, Martins JT, Luis MAV. Relationship between well-being, quality of life and hope in family caregivers of schizophrenic people. Rev Bras Enferm. 2020;73(Suppl 1):e20190359. doi: http://dx.doi.org/10.1590/0034-7167-2019-0359

\section{Corresponding author:} Patricia Dias Francisquini

E-mail: patriciafrancisquini@yahoo.com.br

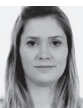

EDITOR IN CHIEF: Antonio José de Almeida Filho ASSOCIATE EDITOR: Fátima Espírito Santo

Submission: 08-03-2019 Approval: 11-19-2019

\begin{abstract}
Objective: To measure and correlate the degree of psychological well-being, quality of life, and dispositional hope in family caregivers of schizophrenic people. Methods: Descriptive cross-sectional study conducted with 117 relatives of schizophrenic people. We applied a questionnaire of sociodemographic variables was applied, and the instruments World Health Organization 5-Item Well-Being (WHO-5), World Health Organization Quality of Life Abbreviated (WHOQOL-Bref), and Dispositional Hope Scale. We used The Kruskal Wallis, Jonckheere-Terpstra, and Spearman correlation tests at the level $a<0.05$. Results: It was possible to observe statistical significance when comparing schooling and age with Disposal Hope; and when comparing the scales used. Conclusion: The study considered that well-being, quality of life, and hope are variables that negatively influence caregiver burden, suggesting schooling as an inverse correlation variable with Dispositional Hope. Descriptors: Family caregiver; Mental health; Schizophrenia; Quality of life; Hope of life.
\end{abstract}

\section{RESUMO}

Objetivo: Mensurar e correlacionar o grau de bem-estar psicológico, qualidade de vida e esperança disposicional em cuidadores familiares de pessoas esquizofrênicas. Métodos: Estudo descritivo, transversal, realizado com 117 familiares de pessoas esquizofrênicas. Foram aplicados um questionário de variáveis sociodemográficas; e os instrumentos World Health Organization 5-Item Well-Being (WHO-5), World Health Organization Quality of Life Abreviado (WHOQOL-Bref) e Escala de Esperança Disposicional. Foram utilizados os testes de Kruskal Wallis, JonckheereTerpstra e correlação de Spearman, em nível a $<0,05$. Resultados: Observou-se significância estatística quando comparada a escolaridade e faixa etária com a Esperança Disposicional; e quando comparadas as escalas utilizadas. Conclusão: $\mathrm{O}$ estudo considerou que o bem-estar, qualidade de vida e esperança são variáveis que influenciam negativamente a sobrecarga do cuidador, sugerindo a escolaridade como variável de relação inversa à Esperança Disposicional. Descritores: Cuidador familiar; Saúde Mental; Esquizofrenia; Qualidade de Vida; Esperança de Vida.

\section{RESUMEN}

Objetivo: Mensurar y correlacionar el grado de bienestar psicológico, calidad de vida y esperanza disposicional en cuidadores familiares de personas esquizofrénicas. Métodos: Estudio descriptivo, transversal, realizado con 117 familiares de personas esquizofrénicas. Han sido aplicados un cuestionario de variables sociodemográficas y los instrumentos: World Health Organization 5-Item Well-Being (WHO-5), World Health Organization Quality of Life Abreviado (WHOQOL-Bref) y Escala de Esperanza Disposicional. Han sido utilizadas las pruebas de Kruskal Wallis, Jonckheere-Terpstra y correlación de Spearman, en nivel a $<0,05$. Resultados: Se ha observado significación estadística cuando comparada la escolaridad y franja etaria con la Esperanza Disposicional y cuando comparadas las escalas utilizadas. Conclusión: El estudio ha considerado que el bienestar, calidad de vida y esperanza, son variables que influencian negativamente la sobrecarga del cuidador, sugiriendo la escolaridad como variable de relación inversa a la Esperanza Disposicional.

Descriptores:Cuidador familiar; Salud Mental; Esquizofrenia; Calidad de Vida; Esperanza de Vida. 


\section{INTRODUCTION}

Mental diseases are considered chronic diseases and a public health problem because of their frequency, affecting about 700 million people worldwide. In this context, schizophrenia is a severe mental disorder, affecting around 21 million people worldwide. It is characterized by distortion of thought, perceptions, language, emotion, self-awareness, and behavior, with the presence of experiences such as delusions and hallucinations. Stigmas and prejudices surround the disease throughout society ${ }^{(1-2)}$. For these reasons, care for this individual with schizophrenia becomes even more arduous, especially for family caregivers.

Assistance to people with mental disorders in order to resocialize and rehabilitate these individuals is part of a recent conception in Brazil. In the 1980s, with the Psychiatric Reform process, the preference for out-of-hospital psychiatric treatment was adopted ${ }^{(3-4)}$. This transition had a significant impact on the family member since this proposal and the inclusion of family participation in the whole process of resocialization and rehabilitation can create overload as the family members had no preparation for to perform such a function ${ }^{(5-8)}$.

Considering that, in the population using public health services, these family members became the principal caregivers, even without preparation/guidance and with little knowledge about the approach to the psychiatric patient in their family life. Several studies researched this theme. It was possible to observe Psychological distress among these family caregivers, called "objective and subjective burden"(9-10).

Experienced researchers ${ }^{(11)}$ define objective burden as excessive patient care, implying financial costs and changes in the caregiver's routine. They characterize subjective burden as the degree of discomfort that the family caregiver perceives or evaluates when treating mental illness. Several studies ${ }^{(4,6,8-9,12)}$ discuss objective and subjective burden and use scales to assess the degree of burden in various types of caregivers. However, there is a gap regarding the relationship of other psychosocial aspects that may also be affected, such as the feeling of well-being, hope, and quality of life.

Overall, it is possible to define the term quality of life (QOL) as personal well-being, including several factors such as happiness, one's emotional state, personal and professional satisfaction, health status, socioeconomic status, self-care, family support, community and living environment ${ }^{(13)}$. The World Health Organization defines QOL as "[...] individuals' perceptions of their position in life in the context of the culture and value systems in which they live and in relation to their goals, expectations, standards and concerns. [...] $]^{\prime \prime(14)}$.

The concept of well-being has been widely studied, and there are different and complementary perspectives on this construct. The most widespread is organized into two perspectives: subjective well-being (SWB) and psychological wellbeing (PWB). SWB aims to identify how happy or satisfied the individuals are and in what areas of their life this is true $\mathrm{e}^{(15)}$, and it is linked to a perspective of well-being as pleasure, happiness, and life satisfaction, i.e., "Feel life" and "think about it"(16);:The PWB, on the other hand, shows how happy or satisfied an individual feels in certain psychological domains, as well as the psychological resources they possess, consisting of human development and the ability to overcome difficulties ${ }^{(15)}$.

Hope is a positive emotional state, with perceptions aimed at achieving a goal, composed by the interaction between pathways and agencies - being the pathways, the planned path to achieve this goal, and agency, the motivation to achieve this goal ${ }^{(17)}$. For hope to exist, a researcher ${ }^{(18)}$ suggests a triad: goal, pathway, and agency. Therefore, to have hope, it is expected that an individual, to reach a goal, presents pathways, that is, presents different ways to reach the goal, together with the motivation (agency) to propel it.

Considering that caregiving creates overload, international studies have found that caregivers may experience mental dysfunction during the process, which decreases their quality of life and well-being levels while increasing suffering and consequently weakens the quality of care for their mentally ill family members ${ }^{(10,19)}$.

International surveys indicate that QOL levels of caregivers of people with mental illness were poor across all domains ${ }^{(19-22)}$, representing $68.3 \%$ of all respondents in a study conducted in China ${ }^{(22)}$ and $57.3 \%$ in a study conducted in Uganda ${ }^{(20)}$. QOL is a multidimensional factor in which physical health, mental health, financial situation, and social life interact with each other ${ }^{(22)}$.

Cross-sectional and literature review studies ${ }^{(23-25)}$ show that the heavier the burden of care, the higher the negative impact on well-being levels and quality of care, exposing significant correlations ${ }^{(24)}$. However, there are no studies correlating the family caregiver of people with schizophrenia with the concomitant scales of well-being, quality of life, and hope. Based on the above, the study aimed at analyzing, in family caregivers of people with schizophrenia, the relationship between well-being, quality of life, and hope.

\section{OBJECTIVE}

To measure and correlate the degree of psychological wellbeing, quality of life, and dispositional hope in family caregivers of schizophrenic people.

\section{METHODS}

\section{Ethical aspects}

The Research Ethics Committee approved this research. Before each interview, the researches applied the Informed Consent Form and made a copy available to the interviewee and one to the interviewer.

\section{Study Design, location, and period}

A cross-sectional and descriptive study following the STROBE guidelines, conducted in a Centro de Atenção Psicossocial III (CAPS III - Center for Psychosocial Care III), located in the northern region of the state of Paraná, southern Brazil. In 2017, according to data from the Brazilian Institute of Geography and Statistics (IBGE), the municipality's population projection was 558,439 inhabitants, with a Human Development Index of 0.788 . The survey took place between December 2017 and June 2018. 


\section{Population: inclusion and exclusion criteria}

The sample consisted of family caregivers of adult schizophrenic patients treated at a CAPS III. The population of patients and their families comprised 320 cases. The sample was obtained from the statistical calculation using the IBM Sample Power v.3.0 program, considering an analysis power of $80 \%$, losses of $10 \%$, and the average standard error of 0.2 . Thus, based on these parameters, the estimated minimum sample required was 114 family members. However, we obtained a sample of 117 subjects. Of these 320 cases, there was a random sampling process, for which we elaborated a numerical sequence for randomization and the subsequent draw of 175 medical records. Inclusion criteria were: to live daily with the patient, to be the primary caregiver, to be over 18 years old. Exclusion criteria: The family caregiver presents some severe mental disorder and does not show an understanding of the questions asked.

There were one exclusion, 17 refusals to participate, and 40 losses, totaling a final sample of 117 individuals.

\section{Study Protocol}

The researcher herself conducted the interviews with the family members during their stay at CAPS III, due to the consultation and the family group, with an application time of approximately 20 minutes. For the relatives not found in this first moment, the researcher made up to three telephone contacts to inform the reason for the call and the interview. After acceptance, the participants scheduled a home visit to perform data collection. We considered the absence of the relative at the previously scheduled date and time as a loss. The interviews took place between December 2017 and June 2018. Data were entered directly into the Google Forms online platform and then tabulated into the Statistical Package for Social Sciences (SPSS) program. We used the following instruments:

\section{World Health Organization 5-Item Well-Being Index (WHO-5)}

The WHO-5, or World Health Organization Wel-Being Index, was developed by a European regional group for psychological well-being assessment and brought together parts of the Psychological General Well-Being Index ${ }^{(26)}$ and the Zung Scales for Anxiety and Depression ${ }^{(27)}$. It has a version validated for Brazil by Souza and Hidalgo(28), with Cronbach's alpha $=0.83$. The questionnaire consists of five questions with values from 0 to 5 points on a Likert scale, with a total score ranging from 0 to 25 . It aims to measure current mental well-being for the last two weeks before the time of the test. According to the validation article conducted in a Brazilian sample ${ }^{(28)}$, a score lower than 20 suggests the presence of depressive disorder, and according to Bech ${ }^{(29)}$, scores less than or equal to 13 indicate impairment of well-being and suggest complementary analyzes for depression.

\section{World Health Organization Quality of Life Instrument - Bref (WHOQOL-Bref)}

The World Health Organization Quality of Life Instrument is an instrument that was developed by a group of WHO QOL researchers. They created it to assess QOL from a cross-cultural perspective to be used in health research, but not exclusively ${ }^{(14)}$.
The WHOQOL-Bref, instrument used in this work, is the abbreviated version of WHOQOL-100. It is composed of 26 questions, two of them related to the general quality of life - Overall Quality of Life Facet (OQOLF) -, and the other 24 questions constitute four domains: physical, psychological, social relationships, and environment. Answers follow a Likert scale, ranging from 1 (very bad; very dissatisfied; nothing; never) to 5 (very good; very satisfied; extremely; always); The higher the score, the better the individual's QOL. It should be noted the need to invert the values ( $1=5,2=4,3=3,4=2,5=1)$ of questions number 3,4 and 26. The WHOQOL-Bref was translated and validated in Brazil by Fleck ${ }^{(30)}$ and presented good internal consistency, with Cronbach's coefficient ranging between 0.71 and 0.84 between domains.

\section{Dispositional Hope Scale}

The Adult Dispositional Hope Scale ${ }^{(17)}$, or Dispositional Hope Scale, was adapted and validated in Brazil through a study ${ }^{(31)}$ with a reliability coefficient of alpha and Cronbach of 0,79 . This instrument has 12 items distributed equally among pathways, agencies, and filter items, according to a 5 -point Likert scale ( 1 = totally false; $5=$ totally true) to assess the level of agreement with each question.

The calculation of the score is made by summing the score obtained in questions 1, 4, 6, 8 (pathways), and 2, 9, 10, 12 (agencies). We do not use questions $3,5,7$, and 11, as they are considered distracting items only. We used a table to interpret the results according to the percentiles and gross scores according to age group. This method is an easy-to-apply, fast-scaling scale with minimal applicator intervention ${ }^{(18)}$.

\section{Results analysis and statistics}

This study analyzed the data with descriptive exploratory analysis, comparison between medians, test for trend, and correlation analysis. For statistical analysis, the Statistical Package for Social Sciences (SPSS), version 25.0, was used. Before performing the statistical analysis itself, the initial step was to perform a normality test in order to choose between parametric (for normal distribution) and nonparametric (for nonnormal) tests. The test applied to evaluate the normality of the sample was the KolmogorovSmirnov test, with Lilliefors correlation, whose results remained at $p<0.001$, classifying the whole sample as non-normal.

Regarding the scales, as no research has previously applied them to family caregivers of people with schizophrenia, it was considered necessary to perform the internal consistency analysis of the scales using Cronbach's alpha coefficient. This approach presented good parameters, with scores of 0.74 for the WellBeing Index (WHO-5), 0.86 for WHOQOL-Bref, and 0.75 for the Dispositional Hope Scale.

We performed the comparisons between educational level and age group with the Well-Being, OQOLF, and Disposition Hope Indexes using the Kruskal-Wallis test, which is indicated for comparisons between three or more groups. The Jonckheere-Terpstra test verified the search for a linear relationship of the positive or negative trend of schooling levels and different age groups with the Well-Being, OQOLF, and Disposition Hope Indexes. Also, to know possible correlations and partial correlations between the 
variables, the Spearman correlation coefficient was used. The significance level adopted was $a<0.05$, and the level $a<0.01$ was also allowed in the Spearman correlation.

Spearman's correlation seeks the existence of a linear relationship between two ordinal variables and can express if there is a positive relationship, that is, the more one variable increases, the more the other related variable also increases. It may also express a negative relationship, meaning that the more one variable increases, the more the other decreases. Thus, the correlation expresses the intensity of the relationship between two variables, and the higher the correlation coefficient, the greater the intensity of this relationship, whose value ranges from -1 to +1 . The interpretation of values varies by author. In this study, values from 0 to 0.2 indicate a very low correlation; 0.2 to 0.4 indicate low correlation; 0.4 to 0.6 indicate moderate correlation; between 0.6 and 0.8 , high; and between 0.8 and 1, very high ${ }^{(32)}$.

\section{RESULTS}

\section{Sociodemographic}

It was possible to identify parents as the primary caregivers, represented by $53.8 \%$. Of the total caregivers, $74.4 \%$ were female, married ( $73.5 \%)$, and with a mean age of 56.7 years (SD \pm 15.7 years), ranging from 18 to 83 years. Regarding education, $35 \%$ of caregivers had between 4 and 7 years of schooling. The predominant family income was between 1 and 2 minimum wages (53.8\%), which was attributed mainly to the benefit received by the patient due to his illness. Of the total, $97.4 \%$ of the caregivers had daily contact with the schizophrenic family member, and the mean time as a caregiver was 13.4 years ( $S D \pm 8.7$ years), with amplitude between 2 and 40 years.

\section{Correlational Analysis}

After performing the Spearman correlation test between age and WHOQOL-Bref domains, both domains are negatively correlated: OQOLFr $=-0.193(p<0.05)$; physical domain, $r=-0.310(p$ $<0.01)$; psychological domain, $r=-0.142(p<0.05)$; environmental domain, $r=-0.221$ ( $p<0.05)$; and with stronger association especially in the domain of social relationships, $r=-0.401(p<0.01)$.

The comparison between education and Dispositional Hope resulted in the value of $p=0.021$ in the Kruskal-Wallis test. For the Jonckheere-Terpstra test, we obtained the values of 2.703 and $p=0.007$. Although the results were statistically significant only when comparing schooling and Dispositional Hope, it is possible to observe, with the Median Test (Table 1), that the higher the schooling (above 8 years of study), the higher the levels of Well-Being, OQOLF, and Hope.

When comparing age and Well-Being Index, OQOLF, and Dispositional Hope, it was possible to observe results similar to those obtained when compared to schooling. Thi study also obtained statistically significant results in relation to Hope, but negatively, with a value of $p=0.005$ in the Kruskal-Wallis test, and for the Jonckheere-Terpstra test, values of -3.186 and $p=$ 0.001 . Although the results are statistically significant only when comparing age and Hope, it is possible to note, with the Median Test (Table 2), that the older the age, the lower the OQOLF levels.
Table 1 - Median Test between schooling, Well-being, Quality of Life and Dispositional Hope, Londrina, Paraná, Brazil, 2018

\begin{tabular}{llcc}
\hline & Schooling & n & Mean rank \\
\hline Well-Being Index & No instruction & 8 & 64.94 \\
& 1 to 3 years & 12 & 63.38 \\
4 to 7 years & 41 & 57.18 \\
8 to 10 years & 38 & 53.29 \\
11 to 14 years & 14 & 64.71 \\
& More than 14 years & 4 & 86.88 \\
& Total & 117 & \\
Neneral & No instruction & 8 & 65.94 \\
Quality of life Index & 1 to 3 years & 12 & 47.75 \\
& 4 to 7 years & 41 & 60.44 \\
& 8 to 10 years & 38 & 52.95 \\
& 11 to 14 years & 14 & 71.32 \\
& More than 14 years & 4 & 78.50 \\
Total & 117 & \\
Dispositional Hope & No instruction & 8 & 25.44 \\
& 1 to 3 years & 12 & 47.17 \\
& 4 to 7 years & 41 & 62.33 \\
& 8 to 10 years & 38 & 60.24 \\
& 11 to 14 years & 14 & 67.46 \\
& More than 14 years & 4 & 86.13 \\
& Total & 117 & \\
\hline
\end{tabular}

Table 2 - Median Test between age group, Well-being, Quality of Life and Dispositional Hope, Londrina, Paraná, Brazil 2018

\begin{tabular}{llcc}
\hline & Age Group & n & Mean rank \\
\hline Well-Being Index & Up to 46 years old & 56 & 55.71 \\
& 47 to 68 years & 30 & 67.82 \\
& 69 years or more & 31 & 56.40 \\
& Total & 117 & \\
General & Up to 46 years old & 56 & 63.21 \\
Quality of life Index & 47 to 68 years & 30 & 56.22 \\
& 69 years or more & 31 & 54.10 \\
Dispositional Hope & Total & 117 & \\
& Up to 46 years old & 56 & 68.15 \\
& 47 to 68 years & 30 & 58.03 \\
& 69 years or more & 31 & 43.40 \\
& Total & 117 & \\
\hline
\end{tabular}

Analyzing the variables of the instruments, we can observe that there are correlations between all existing variables. As can be seen from Table 3 below, all correlations are significant and have a high degree of significance ( $p<0.01$ and $p<0.05)$.

It is observed, by analyzing the variables in Table 3 , that there are significant correlations between all existing variables. We can see that the intensity of the correlation is high $(r=0.6-0.8)$ between the physical domain and the environment domain $(r$ $=0.679$; variance $46.10 \% ; p<0.01$ ). This observation means the higher the levels of the physical domain, the greater the propensity for the levels of the environment domain. Furthermore, when verifying the variance of $46.1 \%$, it can be inferred that such percentages explain the variability between the two constructs, but also implying that there are $53.9 \%$ of the data in which the correlation is explained by other unidentified constructs and thus attributed to other relationships and variables. The same situation happens with the correlation between OQOLF and physical domain ( $r=0.638 ; 40.70 \%$ variance; $p<0.01)$, where other variables explained $59.30 \%$ of the data. 
Table 3 - Matrix of Spearman correlation and variance between the domains of Quality of Life, Well-being and Dispositional Hope, Londrina, Paraná, Brazil, 2018

\begin{tabular}{|c|c|c|c|c|c|c|c|}
\hline & $\begin{array}{l}\text { General } \\
\text { Quality of } \\
\text { Life Index }\end{array}$ & $\begin{array}{l}\text { Quality of } \\
\text { Life-Physical } \\
\text { Domain }\end{array}$ & $\begin{array}{l}\text { Quality of Life } \\
\text { - Psychological } \\
\text { Domain }\end{array}$ & $\begin{array}{c}\text { Quality of } \\
\text { Life-Social } \\
\text { Relationships } \\
\text { Domain }\end{array}$ & $\begin{array}{l}\text { Quality of Life } \\
\text {-Environment } \\
\text { Domain }\end{array}$ & $\begin{array}{l}\text { Well-Being } \\
\text { Index }\end{array}$ & $\begin{array}{c}\text { Dispositional } \\
\text { Hope }\end{array}$ \\
\hline \multicolumn{8}{|c|}{ General Quality of Life Index } \\
\hline$r$ & 1.000 & $0.638^{* *}$ & $0.498^{* *}$ & $0.217^{*}$ & $0.504^{* *}$ & $0.464^{* *}$ & $0.342^{* *}$ \\
\hline Variance & - & $40.70 \%$ & $24.80 \%$ & & $25.04 \%$ & $21.52 \%$ & $11.69 \%$ \\
\hline$p$ value & - & 0.000 & 0.000 & 0.019 & 0.000 & 0.000 & 0.000 \\
\hline \multicolumn{8}{|c|}{ Quality of Life - Physical Domain } \\
\hline$r$ & $0.638^{* *}$ & 1.000 & $0.390^{* *}$ & $0.322^{* *}$ & $0.679^{* *}$ & $0.325^{* *}$ & $0.369^{* *}$ \\
\hline Variance & $40.70 \%$ & - & $15.21 \%$ & $10.36 \%$ & $46.10 \%$ & $10.56 \%$ & 13.61 \\
\hline$p$ value & 0.000 & - & 0.000 & 0.000 & 0.000 & 0.000 & 0.000 \\
\hline \multicolumn{8}{|c|}{ Quality of Life - Psychological Domain } \\
\hline$r$ & $0.498^{* *}$ & $0.390^{* *}$ & 1.000 & $0.442^{* *}$ & $0.437^{* *}$ & $0.464^{* *}$ & $0.479^{* *}$ \\
\hline Variance & $24.80 \%$ & $15.21 \%$ & - & $19.53 \%$ & $19.09 \%$ & $21.52 \%$ & $22.94 \%$ \\
\hline \multicolumn{8}{|c|}{ Quality of Life-Social Relationships Domain } \\
\hline$r$ & $0.217^{*}$ & $0.322^{* *}$ & $0.442^{* *}$ & 1.000 & $0.290^{* *}$ & $0.202^{*}$ & $0.595^{* *}$ \\
\hline Variance & $4.70 \%$ & $10.36 \%$ & $19.53 \%$ & - & $8.41 \%$ & 4.08 & $35.40 \%$ \\
\hline$p$ value & 0.019 & 0.000 & 0.000 & - & 0.002 & 0.029 & 0.000 \\
\hline$p$ value & 0.000 & 0.000 & - & 0.000 & 0.000 & 0.000 & 0.000 \\
\hline \multicolumn{8}{|c|}{ Quality of Life - Environment Domain } \\
\hline$r$ & $0.504^{* *}$ & $0.679^{* *}$ & $0.437^{* *}$ & $0.290^{* *}$ & 1.000 & $0.256^{* *}$ & $0.420^{* *}$ \\
\hline Variance & $25.40 \%$ & $46.10 \%$ & $19.09 \%$ & $8.41 \%$ & - & $6.55 \%$ & 17.64 \\
\hline$p$ value & 0.000 & 0.000 & 0.000 & 0.002 & - & 0.005 & 0.000 \\
\hline \multicolumn{8}{|c|}{ WHO Well-Being Index } \\
\hline$r$ & $0.464^{* *}$ & $0.325^{* *}$ & $0.464^{* *}$ & $0.202^{*}$ & $0.256^{* *}$ & 1.000 & $0.317^{* *}$ \\
\hline Variance & $21.52 \%$ & $10.56 \%$ & $21.52 \%$ & $4.08 \%$ & $6.55 \%$ & - & $10.04 \%$ \\
\hline$p$ value & 0.000 & 0.000 & 0.000 & 0.029 & 0.005 & - & 0.001 \\
\hline \multicolumn{8}{|c|}{ Dispositional Hope } \\
\hline$r$ & $0.342^{* *}$ & $0.369^{* *}$ & $0.479^{* *}$ & $0.595^{* *}$ & $0.420^{* * *}$ & $0.317^{* * *}$ & 1.000 \\
\hline Variance & $11.69 \%$ & $13.61 \%$ & $22.94 \%$ & $35.40 \%$ & $17.64 \%$ & $10.04 \%$ & - \\
\hline$p$ value & 0.000 & 0.000 & 0.000 & 0.000 & 0.000 & 0.001 & - \\
\hline
\end{tabular}

Note: * Statistically significant correlation $(p<0.05) ;{ }^{*}$ Statistically significant correlation $(p<0.01)$.

We observed a moderate correlation $(r=0.4-0.6)$ between the psychological and environment domains $(r=0.437)$; psychological and social relationships $(r=0.442)$; psychological and OQOLF ( $r=0.498)$; psychological domain and Well-being $(r=0.464)$; psychological domain and Dispositional Hope $(r=$ 0.479); environment domain and Disposition Hope $(r=0.420)$; environmental domain and OQOLF $(r=0.504)$; social relationships domain and Disposition Hope $(r=0.595)$; and between Well-being and domain $(r=0.464)$.

When we analyzed variables according to partial correlation, by excluding one variable and measuring the degree of association between the two remaining variables, a true correlation between them is exposed. Thus, we observed new values that showed a significant correlation between the Well-being Index and the OQOLF ( $r=0.479 ; p<0.01)$. The same fact occurs between the Well-being Index and Dispositional Hope $(r=0.221 ; p<0.05)$.

\section{DISCUSSION}

International studies ${ }^{(23-24)}$ conducted with family caregivers of patients with mental disorders, found negatively significant correlations between age and WHOQOL-Bref domains, corroborating the present study. Thus, it can be inferred that to the family caregiver of schizophrenic people, the older they are, the worse the quality of life levels are, given the probably accumulated fatigue and physical and mental exhaustion.
According to the results of the statistical analysis by the KruskalWallis test ( $p=0.021)$ and Jonckheere-Terpstra $(2.703 ; p=0.007)$, it was possible to find statistical significance when comparing schooling and Dispositional Hope. These results suggest that there is a tendency that the more years of schooling, the higher the motivation and pathways pursued by these caregivers to achieve a goal, and that there are significant differences in the degree of hope and education compared to other constructs. Also, due to the linear trend, the more education the individual has, the more hope they tend to have.

Through the results presented through the Median Test, we can observe that the higher the education level (above 8 years of study), the higher the levels of Well-being, OQOLF, and Hope. This event shows us that having a higher level of knowledge favors the development of beneficial factors in relation to subjective feelings felt and experienced. International studies ${ }^{(24,26,33)}$, found data to confirm this trend so that QOL and Well-being levels increased as the level of education increased. Thus, considering these data, it is essential to reflect that caregivers with higher levels of education, associated with better understanding of the disease, its consequences and ways of managing the problems, results in a better adaptation to the role of care, i.e., they can provide better care to their sick family member ${ }^{24,27)}$.

We also obtained statistically significant results by the KruskalWallis $(p=0.005)$ and Jonckheere-Terpstra $(-3.186 ; p=0.001)$ tests regarding the comparison between age group and Hope, but in the negative sense. In this case, the older an individual is, the lower the Hope level. We note that the same fact occurs with the OQOLF; 
that is, the stress generated by the burden of the care provided causes, in the family caregiver, a feeling of helplessness, making him weakened and helpless ${ }^{(34)}$. Moreover, over the years, the levels of hope and QOL significantly decrease, as caring for a patient who has no expectation of cure brings even more hopelessness and lower QOL levels. International surveys found similar results ${ }^{(23-24,26)}$, which negatively correlated QOL and Well-being levels with age.

This study found significant correlations between all variables of the instruments used. A study conducted in Spain ${ }^{(35)}$ analyzed the correlations between Well-being and quality of life, and obtained similar results, with significant moderate-high correlations $(r>0.50)$ among all variables, except for the correlation between Well-being and the domain of the social relationships $(r=0.372)$. We found no studies correlating the three instruments.

\section{Study Limitations}

Among the limitations of this study, the main ones can be considered the lack of studies related to the family caregiver of people with schizophrenia, especially regarding the use of the scales used in the present study to measure the subjective constructs in question - with the same statistical rigorous procedures performed in the present study - which precludes comparison with other locations or populations more precisely.

Therefore, due to the number of data collection instruments used in the present study, it was avoided to add other scales that, a priori, evaluate the burden of the family member and also the level of psychological distress, which was already used in this same population studied. These instruments could complement the analysis from the theoretical point of view since such studies previously conducted with this same population suggested that the burden of care exists ${ }^{(36)}$, accompanied by a high degree of psychological distress ${ }^{(37)}$. However, it could have no practical effect, as it would significantly increase the number of scales used, consequently diminishing the reliability of the responses would

\section{Contributions to nursing, health, or public policy fields}

Thus, based on these assumptions, once mental health nurses understand their extreme importance in recognizing the negative implications caused by the act of caring for these family members, it is expected that they can develop care planning for these individuals in their practice, considering the older the family caregivers, the less hope, well-being and quality of life they will present. Such a scenario would also indirectly benefit people with schizophrenia, as they receive better care and support for social reintegration, which contributes to the implementation of the Psychosocial Care Network.

\section{CONCLUSION}

We verified the relationship between educational level and age with hope. Thus, the more years of education the caregivers had, the more hope they had, and the older they were, the lower their hope. The present study showed the importance of measuring the three constructs, as both were negatively correlated. The unexplained variance data suggest the existence of other variables present in the context, but which this study did not identify, and this suggests the existence of more related constructs.

Notwithstanding the limitations, the study has brought significant advances regarding the perspective of benefits for caregivers, people with schizophrenia, and health professionals, mainly the nurse of mental health services, who, incorporating such knowledge in their practice. , could undertake mental health care planning. For this, the professional would take into account the age of the caregiver as a variable of more considerable attention and care, promote debate for the reformulation of the routine of mental health services and policies, and would plan interventions to reduce care burden given the high degree of stress.

It should be conceivable to include family caregivers as vulnerable groups from a certain age and time as a caregiver. Then, they would receive medical, psychological, and inclusion in family support groups in order to try to prevent psychological distress. This actions would contribute to the improvement of well-being, QOL and the sense of hope of these family caregivers; reflect on the best care given to their families; and would implement the strategy of psychosocial rehabilitation with the Psychosocial Care Network, which does not happen nor is it effective nor does it exist without proper family participation.

\section{REFERENCES}

1. World Health Organization-WHO. Schizophrenia. WHO: Geneva. [Internet]. 2018 [cited 2018 Sep 1]. Available from: http://www.who.int/es/ news-room/fact-sheets/detail/schizophrenia

2. Perkins A, Ridler J, Browes D, Peryer G, Notley C, Hackmann C. Experiencing mental health diagnosis: a systematic review of service user, clinician, and carer perspectives across clinical settings. Lancet Psychiatry. 2018;5(9):747-64. doi: 10.1016/S2215-0366(18)30095-6

3. Amarante P, Nunes MO. A reforma psiquiátrica no SUS e a luta por uma sociedade sem manicômios. Cienc Saúde Colet. 2018;23(6):2067-74. doi: 10.1590/1413-81232018236.07082018

4. Tabeleão VP, Tomasi E, Quevedo LA. Sobrecarga de familiares de pessoas com transtorno psíquico: níveis e fatores associados. Rev Psiquiatr Clin. 2014;41(3):63-6. doi: 10.1590/0101-60830000000012

5. Cavalheri SC. Transformações do modelo assistencial em saúde mental e seu impacto na família. Rev Bras Enferm. 2010;63(1):51-57. doi: 10.1590/S0034-71672010000100009

6. Reis TL dos, Dahl CM, Barbosa SM, Teixeira MR, Delgado PGG. Sobrecarga e participação de familiares no cuidado de usuários de Centros de Atenção Psicossocial. Saúde debate. 2016;40(109):70-85. doi: 10.1590/0103-1104201610906 
7. Oliveira EM, Eloia SMC, Lima DS, Eloia SC, Linhares AMF. A família não é de ferro: ela cuida de pessoas com transtorno mental. Rev Pesqui: Cuid Fundam. 2017;9(1):71-8. doi: 10.9789/2175-5361.2017.v9i1.71-78

8. Delgado PG. Sobrecarga do cuidado, solidariedade e estratégia de lida na experiência de familiares de Centros de Atenção Psicossocial. Physis. 2014;24(4):1103-26. doi: 10.1590/S0103-73312014000400007

9. Barroso SM, Bandeira M, Nascimento E do. Sobrecarga de familiares de pacientes psiquiátricos atendidos na rede pública. Rev Psiquiatr Clin. 2007;34(6):270-7. doi: 10.1590/\$0101-60832007000600003

10. Chen X, Mao Y, Kong L, Li G, Xin M, Lou F, Li P. Resilience moderades the association between stigma and psychological distress among family caregivers of pacients with schizophrenia. Pers Individ Dif. 2016;96(7):78-82. doi: https://dx.doi.org/10.1016/j.paid.2016.02.062

11. Maurin JT, Boyd CB. Burden of mental illness on the family: a critical review. Arch Psychiatr Nurs. 1990. 4(2):99-107. doi: 10.1016/0883-9417(90)90016-E

12. Nolasco M, Bandeira M, Oliveira MS de, Vidal CEL. Sobrecarga de familiares cuidadores em relação ao diagnóstico de pacientes psiquiátricos. J Bras Psiquiatr. 2014;63(2):89-97. doi: 10.1590/0047-2085000000011

13. Vecchia RD, Ruiz T, Bocchi SCM, Corrente JE. Qualidade de vida na terceira idade: um conceito subjetivo. Rev Bras Epidemiol. 2005 Sep;8(3):246-252. doi: 10.1590/S1415-790X2005000300006

14. World Health Organization. WHOQOL user manual. Geneva (Switzerland): World Health Organization [Internet]. 1998 [cited 2018 Apr 28]. Available from: https://www.who.int/mental_health/evidence/who_qol_user_manual_98.pdf

15. Ryff, C. D. Hapiness is everything, or is it? Explorations on the meaning of psychological well-being. J Pers Soc Psychol. 1989. 57(6):1069-81. doi: 10.1037/0022-3514.57.6.1069

16. Henna E, Zilberman M, Gorenstein C. Instrumentos de avaliação do bem-estar. In: Gorenstein C, Wang Y, et al (Eds.). Instrumentos de avaliação em saúde mental. Porto Alegre: Artmed, 2016. p. 456-461.

17. Snyder CR, Harris C, Anderson JR, Holleran AS, Irving LM, Sigmon ST, Yoshinobu LR, Gibb J, Langelle C, Harney P. The will and the ways: development of an individual differences measure of hope. J Pers Soc Psychol. 1991. 60: 570-585. doi: 10.1037/0022-3514.60.4.570

18. Pacico JC, Bastianello MR. Instrumentos para avaliação da esperança: escala de esperança disposicional e escala de esperança cognitiva. In: Hutz C. Avaliação em Psicologia Positiva. Porto Alegre: Artmed, 2014. p. 101-110.

19. Ruchika A, Kumar R, Varghese A. Depression and quality of life in family caregivers of individuals with psychiatric illness. Int J Community Med Public Health. 2019 Feb;6(2):715-20. doi: http://dx.doi.org/10.18203/2394-6040.ijcmph20190196

20. Ndikuno C, Namutebi M, Kuteesa J, Mukunya D, Olwit C. Quality of life of caregivers of patients diagnosed with severe mental illness at the national referral hospitals in Uganda. BMC Psych. 2016;16:400. doi: 10.1186/s12888-016-1084-2

21. Neong SC, Rashid A. Quality of life of caregivers of patients with psychiatric illness in Penang. J Clin Psychiatry Cog Psychol [Internet]. 2018 [cited 2019 Apr 21];2(1):12-8. Available from: http://www.alliedacademies.org/abstract/quality-of-life-of-caregivers-of-patients-withpsychiatric-illness-in-penang-10015.html

22. Leng A, Xu C, Nicholas E, Nicholas F, Wang J. Quality of life in caregivers of a family member with serious mental illness: Evidence from China. Arch Psychiatr Nurs. 2019;33(1):23-9. doi: 10.1016/j.apnu.2018.08.010

23. Gupta A, Solanki RK, Koolwal GD, Gehlot S. Psychological well-being and burden in caregivers of patients with schizophrenia. Int J Med Sci Public Health. 2015;4(1):70-6. doi: 10.5455/ijmsph.2015.0817201416

24. Mohammed SFM, Ghaith RFAH. Relationship between burden, psychological well-being, and social support among caregivers of mentally ill patients. Egypt Nurs J. 2018;15(3):268-80. doi: 10.4103/ENJ.ENJ_17_18

25. Singh G, Dubey A. Mental health and well-being of caregivers: a review of the literature. Int J Indian Psychol [Internet]. 2016 [cited 2019 Apr 21];3(4):98-105. Available from: https://ijip.in/articles/mental-health-and-well-being-of-caregivers-a-review-of-the-literature/

26. Rasmussen N, Norholm V, Bech P. The internal and external validity of the Psychological General Well-Being Schedule (PGWB). QoL Newsletter. 1999. 22:7.

27. Zung WW. A Self-Rating Depression Scale. Arch Gen Psych. 1965;12:63-70. doi: 10.1001/archpsyc.1965.01720310065008

28. Souza CM de, Hidalgo MPL. World Health Organization 5-item Well-Being Index: validation of the Brazilian Portuguese version. Eur Arch Psych Clin Neurosci. 2012 Apr. 262(3):239-44. doi: 10.1007/s00406-011-0255-x.2012.262(3):239-244

29. Bech P. Measuring the dimension of psychological general well-being by the WHO-5. QoL Newsletter [Internet]. 2004 [cited 2019 Apr 2];32: 15-16. Available from: https://research.ncl.ac.uk/sparcle/Publications_files/QOL\%20paper.pdf

30. Fleck MPA, Louzada S, Xavier M, Chachamovich E, Vieira G, Santos L, Pinzon V. Aplicação da versão em português do instrumento abreviado de avaliação da qualidade de vida "WHOQOL-bref". Rev Saúde Pública. 2000 Apr;34(2):178-183. doi: 10.1590/S0034-89102000000200012

31. Pacico JC, Bastianello MR, Hutz CS. Adaptation and validation of the dispositional hope scale for adolescents. Psicol Reflex Crit. 2013;26(3):488-492. doi: 10.1590/S0102-79722013000300008

32. Bisquerra R, Sarriera JC, Martínez F. Introdução à estatística. Porto Alegre: Artmed, 2004. 256 p.

33. Opoku-Boateng YN, Kretchy IA, Aryeetey GC, Dwomoh D, Decker S, Agyemang SA, Nonvignon J. Economic cost and quality of life of family caregivers of schizophrenic patients attending psychiatric hospitals in Ghana. BMC Health Serv Rev. 2017;17(2):697. doi: 10.1186/ s12913-017-2642-0 
34. Lima ICS, Lima SBDA. Vivenciando sentimentos e fragilidades do cuidar em esquizofrenia: visão de familiares cuidadores. Rev Pesqui: Cuid Fundam. 2017 Dec;9(4):1081-6. doi: 10.9789/2175- 5361.2017.v9i4. 1081-1086

35. Lucas-Carrasco R. Reliability and validity of the Spanish version of the World Health Organization-Five Well-Being Index in elderly. Psych Clin Neurosci. 2012;66(6):508-513. doi: 10.1111/j.1440-1819.2012.02387.x

36. Soares MH, Farinasso ALC, Gonçalves CS, Machado FP, Mariano LKFR, Santos CD. Overload and satisfaction of family members of Patients with schizophrenia. Cogitare Enferm]. 2019;24:e54729. doi: 10.5380.ce.v24i0.54729

37. Soares MH, Ceciliano DTD. Stress and satisfaction of family members and independent living skills of psychiatric outpatients. Arch. Clin. Psychiatry. 2014;41(6):138-41. doi: 10.1590/0101-60830000000031 